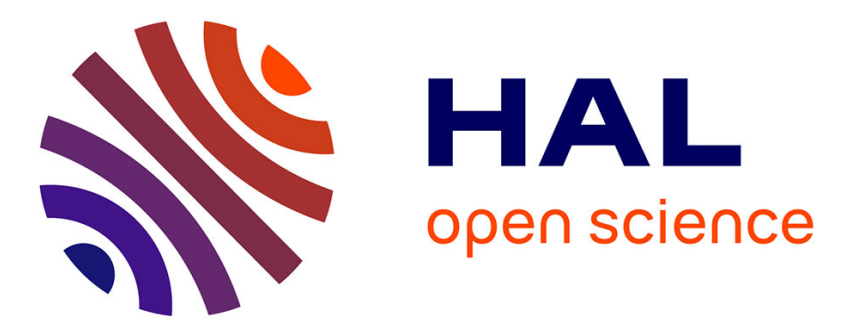

\title{
Nitrogen Revising of Rapeseed (Brassica napus L.) Phenology and Leaf Number Models
}

Hongxin Cao, Yan Liu, Wenyu Zhang, Yeping Zhu, Daokuo Ge, Yanbin Yue, Yongxia Liu, Jinying Sun, Zhiyou Zhang, Yuli Chen, et al.

\section{- To cite this version:}

Hongxin Cao, Yan Liu, Wenyu Zhang, Yeping Zhu, Daokuo Ge, et al.. Nitrogen Revising of Rapeseed (Brassica napus L.) Phenology and Leaf Number Models. 8th International Conference on Computer and Computing Technologies in Agriculture (CCTA), Sep 2014, Beijing, China. pp.54-66, 10.1007/978-3-319-19620-6_7 . hal-01420291

\section{HAL Id: hal-01420291 \\ https://hal.inria.fr/hal-01420291}

Submitted on 20 Dec 2016

HAL is a multi-disciplinary open access archive for the deposit and dissemination of scientific research documents, whether they are published or not. The documents may come from teaching and research institutions in France or abroad, or from public or private research centers.
L'archive ouverte pluridisciplinaire HAL, est destinée au dépôt et à la diffusion de documents scientifiques de niveau recherche, publiés ou non, émanant des établissements d'enseignement et de recherche français ou étrangers, des laboratoires publics ou privés.

\section{(c)(1)}

Distributed under a Creative Commons Attribution| 4.0 International License 


\title{
Nitrogen revising of rapeseed (Brassica napus L.) phenology and leaf number models
}

\author{
Hongxin $\mathrm{Cao}^{1, \mathrm{a}}$, Yan Liu ${ }^{1, \mathrm{~b}}$, Wenyu Zhang ${ }^{1, \mathrm{c}}$, Yeping $\mathrm{Zhu}^{2, \mathrm{~d}}$, Daokuo Ge ${ }^{1, \mathrm{e}}$, Yanbin Yue ${ }^{3, \mathrm{f}}$, \\ Yongxia Liu, ${ }^{4, g}$, Jinying Sun ${ }^{5, \mathrm{~h}}$, Zhiyou Zhang ${ }^{6, \mathrm{i}}$, Yuli Chen ${ }^{1, \mathrm{j}}$, Weixin Zhang ${ }^{1, \mathrm{k}}$, Kunya Fu ${ }^{1,1}$, \\ $\mathrm{Na} \mathrm{Liu}^{7, \mathrm{~m}}$, Chunhuan Feng ${ }^{1, \mathrm{n}}$, Taiming Yang ${ }^{8, \mathrm{o}}$ \\ ${ }^{I}$ Institute of Agricultural Economics and Information; Engineering Research Center for Digital \\ Agriculture, Jiangsu Academy of Agricultural Sciences, Nanjing 210014, Jiangsu Province, P.R. \\ China \\ ${ }^{2}$ Institute of Agricultural Information, China Academy of Agricultural Sciences, Beijing 100081, P.R. \\ China \\ ${ }^{3}$ Institute of Agricultural Sci-tech Information, Guizhou Academy of Agricultural Sciences, Guiyang \\ 550000, Guizhou Province, P.R. China \\ ${ }^{4}$ Institute of Banana and Plantain/Haikou Experimental Station, Chinese Academy of Tropical \\ Agricultural Sciences, Haikou 570102, Hainan Province, P.R. China \\ ${ }^{5}$ Agricultural Technological Extensive Station of Luntai County in Xinjiang, Luntai 841600 , \\ Xinjiang, P.R. China \\ ${ }^{6}$ Institute of Agricultural Sci-tech Information, Hunan Academy of Agricultural Sciences, Changsha \\ 410000, Hunan Province, P.R. China \\ ${ }^{7}$ Center for China Meteorological Information, China Meteorological Bureau, Beijing 100000, P.R. \\ China \\ ${ }^{8}$ Institute of Agricultural Meteorology, Anhui Provincial Meteorological Bureau, Hefei 230000, P.R. \\ China \\ acaohongxin@hotmail.com, ${ }^{b}$ liuyan0203@yahoo.com.cn, ${ }^{c}$ aunote@163.com, ${ }^{\mathrm{d}}$ zhuyeping@.caas.cn, \\ egedk@sina.com, ${ }^{\mathrm{f}}$ yanbin1220@163.com, ${ }^{\mathrm{g}}$ liuyongxia0926@163.com, ${ }^{\mathrm{h}}$ sunjinying240@,sina.com,

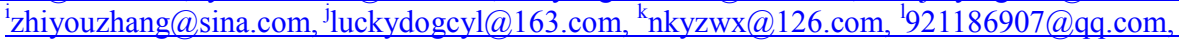

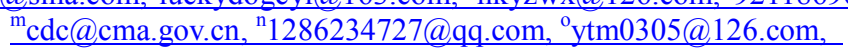

Abstract The Decision-making System for Rapeseed Optimization-Digital
Cultivation Based on Simulation Models, DSRODCBSM, is a dynamic model that
describes the growth and development of winter rapeseed. In order to perfect
rapeseed growth models, Ningyou16 (NY16), Ningyou 18 (NY18), and Ningza 19
(NZ19) were adopted as materials, and the field experiments with 2 cultivars and 2
nitrogen levels, and pot experiment with 3 cultivars and 2 nitrogen levels were
conducted during 2007-2008, 2008-2009, and 2011-2012 in Nanjing, respectively.
The experimental results showed that the phenology and leaf number in rapeseed
models had obvious difference for the same cultivars under different nitrogen levels.
Thus, the nitrogen effect factor, F (N), was put forward, used in the phenology
sub-model in rapeseed growth models, and the verification of the leaf number
sub-model can be done through model parameter adjusting. The simulated values
before and after using F (N) and the observed values were compared, and the
precision for the phenology sub-models in rapeseed growth models were raised
further. 
Keywords: nitrogen impact, rapeseed (Brassica napus L.), phenology models, leaf number models, revising

\section{Introduction}

Rapeseed is one of very important oilseed crops in the world, and its plant area in normal year is about 18-30 million ha. The plant area of rapeseed in China is about 6-7 million ha, and its total yields is about 10-13 million tons, which ranks the fifth place in crop production in China [1]. It plays a very significant role in ensuring cooking oil and plant protein supply, and promoting farmer income increase that makes rapeseed production stable sustainable growth. However, the good cultivars and the relevant advanced management techniques are very important to promote rapeseed production with high yield, good quality, high benefit, ecology, and safety. In that the rapeseed growth models is an important basis of rapeseed precision management techniques.

In recent years, studies on rapeseed crop models have made rapid progress. Notably, some rapeseed growth and development models, and ecological system models, e.g. EPR95 (erosion-productivity influence calculator, EPIC-Rape) [2], DAR95 (differential algebra for identifiability of systems, DAISY- Rape) [3], LINTUL-BRASNAP (light interception and utilization simulator) [4], CERES-rape (crop environment resource synthesis) [5], APSIM-Canola (agricultural production systems simulator) [6], and CECOL [7], etc. had been developed which can simulate rapeseed growth and development in real time. In China, the research on rapeseed growth model was not more. Liu and Jin [8], and Liu et al. [9] set up rapeseed phenology model etc. Zhang et al. [10], Cao et al. [11-14], and Tang et al. [15,16] studied the rapeseed growth and development simulation models, optimization models for rapeseed cultivation, and soil moisture and nitrogen dynamic models during rapeseed growth season, and the Decision-making System for Rapeseed Optimization-Digital Cultivation Based on Simulation Models (DSRODCBSM) were developed combining the rapeseed growth models (including phenology, leaf number, biomass, leaf area index (LAI), and shoot number dynamic models, etc.), the rapeseed optimization models (including the optimum season, the optimum LAI, the optimum shoot numbers, the optimum sowing rate, the optimum fertilization rate, and the optimum soil moisture, etc.), and expert knowledge of rapeseed plant diseases and insect pests, based on field experiments in Yangtz river middle valley of China [11], employing ideas of Rice or Wheat Cultivation-Simulation-Optimization-Decision making System (R/WCSODS) [17,18]. However, the rapeseed phenological models, and the leaf number models in DSRODCBSM were established under the optimum soil nitrogen, and water conditions, etc., if they were used in different soil nitrogen, and water conditions, there must be some errors in their results.

The objectives of this study were to introduce the effect factor of nitrogen in the phenology and leaf number sub-model (APPENDIX A, and B) in rapeseed growth models based on the field and pot experiments during 2007-2008, 2008-2009, and 2011-2012 in Nanjing, test, and perfect rapeseed growth models. 


\section{Materials and Methods}

\subsection{Materials}

"Ningyou16" (NY16, conventional), "Ningyou18" (NY18, conventional), and "Ningza 19" (NZ19, hybrid) (breed by Institute of Economic Crops Research, Jiangsu Academy of Agricultural Sciences) were used in the experiments.

\subsection{Methods}

Experiment 1: The rapeseed cultivars, "NY16", and "NY18", were grown in the field from 2007 to 2008 on Yellow umber soil with higher fertility in pre-planting in soil in Nanjing $\left(32^{\circ} 03^{\prime} \mathrm{N}\right)$, Jiangsu Province. The experiment included 2 cultivars and 2 nitrogen levels (Fertilizer: $0.018 \mathrm{~kg} \mathrm{~N} \cdot \mathrm{m}^{-2} ; 0.012 \mathrm{~kg} \mathrm{P}_{2} \mathrm{O}_{5} \cdot \mathrm{m}^{-2} ; 0.018 \mathrm{~kg} \mathrm{~K} \mathrm{~K}_{2} \mathrm{O} \cdot \mathrm{m}^{-2}$; and $0.0015 \mathrm{~kg}$ borax $\cdot \mathrm{m}^{-2}$; CK: no fertilizer), 4 treatments, 3 replications, 12 subplots arranged random with $40.0-\mathrm{cm}$ row spacing, $17-20 \mathrm{~cm}$ plant spacing in $7.00-$ by $4.30-\mathrm{m}$ area, and the sowing date was on 26 SEP 2007. Fertilizing and other field managements in plots were the same.

Experiment 2: The rapeseed cultivars, "NY16", "NY18", and "NZ 19", were grown in the pot from 2008 to 2009 on Yellow umber soil with higher fertility in pre-planting in soil in Nanjing $\left(32^{\circ} 03^{\prime} \mathrm{N}\right)$, Jiangsu Province. The experiment included 3 cultivars and 2 nitrogen levels (Fertilizer: $0.018 \mathrm{~kg} \mathrm{~N} \cdot \mathrm{m}^{-2} ; 0.012 \mathrm{~kg} \mathrm{P}_{2} \mathrm{O}_{5} \cdot \mathrm{m}^{-2} ; 0.018 \mathrm{~kg} \mathrm{~K} \mathrm{~K}_{2} \mathrm{O} \cdot \mathrm{m}^{-2}$; and $0.0015 \mathrm{~kg}$ borax $\cdot \mathrm{m}^{-2}$; CK: no fertilizer), 4 treatments, 5 replications, and 20 pots, and the sowing date was on 28 SEP 2008. Fertilizing and other field managements in plots were the same.

Experiment 3: The rapeseed cultivars, "NY16", "NY18", and "NZ 19", were grown in the field from 2011 to 2012 on Yellow umber soil with higher fertility in pre-planting in soil in Nanjing $\left(32^{\circ} 03^{\prime} \mathrm{N}\right)$, Jiangsu Province. The experiment included 3 cultivars and 2 nitrogen levels (Fertilizer: $0.018 \mathrm{~kg} \mathrm{~N} \cdot \mathrm{m}^{-2} ; 0.012 \mathrm{~kg} \mathrm{P}_{2} \mathrm{O}_{5} \cdot \mathrm{m}^{-2} ; 0.018 \mathrm{~kg} \mathrm{~K} \mathrm{~K}_{2} \mathrm{O} \cdot \mathrm{m}^{-2}$; and

$0.0015 \mathrm{~kg}$ borax $\cdot \mathrm{m}^{-2}$; CK: no fertilizer), 6 treatments, 3 replications, and 18 subplots arranged random with $40.0-\mathrm{cm}$ row spacing, $17-20 \mathrm{~cm}$ plant spacing in $7.00-$ by $4.30-\mathrm{m}$ area, and the sowing date was on 15 OCT 2011. Fertilizing and other field managements in plots were the same.

The soil type of the experimental area is a hydragric anthrosol. Soil test results indicated the following: organic carbon, $13.7 \mathrm{~g} \mathrm{~kg}^{-1}$; total nitrogen, $54.95 \mathrm{~g} \mathrm{~kg}^{-1}$; available phosphorus, $24.25 \mathrm{~g} \mathrm{~kg}^{-1}$; available potassium, $105.03 \mathrm{~g} \mathrm{~kg}^{-1}$; and $\mathrm{pH}, 7.84$.

\subsubsection{Data Collection}


The phenophase, LAI, the total shoot numbers, dry matter, leaf number, leaf photosynthesis, plant characters, and soil data, etc. were observed during rapeseed growth or after harvest.

The meteorological data during the experiments were down from Center for China Meteorological Information of China Meteorological Bureau.

\subsubsection{Data Process}

In this study, Excel.2007 and SPSS V 16.0 were used to analysis experimental data. The experiment data in 2008-2009 were applied to model establishment and parameter determination, and the experiment data in 2007-2008, and 2011-2012 were applied to model verification.

\subsubsection{Model Verification}

Simulation values were calculated in DSRODCBSM, and model precision was verified using root mean squared error $(R M S E)$, mean absolute error $\left(d_{a}\right)$, the ratio of $\mathrm{d}_{\mathrm{a}}$ to the mean observation $\left(d_{a p}\right)$ [19], the determined coefficient $\left(R^{2}\right)$, and 1:1 plotting between measured values and simulated values. If $d a$ and $R M S E$ were smaller and $R^{2}$ was larger, the simulated values were better agree with measured values, i.e. the deviation between simulated values and measured values was smaller, and simulation results of model were more accurate and reliable. The calculation formula of $R M S E$ and $d a$ can be expressed as follows:

$$
\begin{array}{r}
\text { RMSE }=\sqrt{\frac{1}{n} \sum_{i=1}^{m}\left(x_{\mathrm{Oi}}-x_{S i}\right)^{z}} \\
d_{\mathrm{ai}}=\frac{1}{\mathrm{n}} \sum_{\mathrm{i}=1}^{\mathrm{m}}\left(\mathrm{x}_{\mathrm{Oi}}-\mathrm{x}_{\mathrm{Si}}\right) \\
\mathrm{d}_{\mathrm{ap}}(\%)=\| \mathrm{d}_{\mathrm{a}} / / \overline{\mathrm{x}}_{\mathrm{O}} \times 100 \\
\overline{\mathrm{x}}_{\mathrm{O}}=\frac{1}{\mathrm{n}} \sum_{\mathrm{i}=1}^{\mathrm{n}} \mathrm{x}_{\mathrm{Oi}}
\end{array}
$$

where $X_{\mathrm{O} i}$ is observed values, $X_{\mathrm{Si}}$ is simulated values, $d_{a}$ is absolute error, $\left|d_{\mathrm{a}}\right|$ is a absolute value of $d_{a}, d_{a p}$ is the ratio of $\mathrm{d}_{\mathrm{a}}$ to the mean observation, and $n$ is sample numbers.

\section{Results}

\subsection{The phenology and leaf number under the different nitrogen rate}

3.1.1 Phenology. Under the local normal sowing date in 2007-2008, the phenology of different nitrogen levels for same cultivars had obvious difference at enlongation, and the 
enlongation date under $\mathrm{N}$ application conditions were later than that of $\mathrm{CK}$. But the mature dates were not difference (Table 1).

Table 1. The phenology under different cultivars and nitrogen rate in 2007-2008

\begin{tabular}{|c|c|c|c|c|c|c|}
\hline Cultivars & Fertilizer & Sowing date (M-D) & $\begin{array}{l}\text { Emergence date } \\
\text { (M-D) }\end{array}$ & $\begin{array}{l}\text { Enlongation date } \\
\text { (M-D) }\end{array}$ & $\begin{array}{l}\text { Early anthesis date } \\
\text { (M-D) }\end{array}$ & $\begin{array}{l}\text { Mature date } \\
\text { (M-D) }\end{array}$ \\
\hline \multirow[t]{2}{*}{ NY16 } & $\mathrm{N}$ & $09-26$ & $09-29$ & 03-11 & $03-25$ & $05-16$ \\
\hline & CK & $09-26$ & 09-29 & 03-08 & $03-25$ & $05-16$ \\
\hline \multirow[t]{2}{*}{ NY18 } & $\mathrm{N}$ & $09-26$ & $09-29$ & 03-11 & $03-25$ & $05-16$ \\
\hline & CK & $09-26$ & $09-29$ & 03-08 & 03-25 & $05-16$ \\
\hline
\end{tabular}

Note: $\mathrm{N}$ represents Fertilizer: $0.018 \mathrm{~kg} \mathrm{~N} \cdot \mathrm{m}^{-2} ; 0.012 \mathrm{~kg} \mathrm{P}_{2} \mathrm{O}_{5} \cdot \mathrm{m}^{-2} ; 0.018 \mathrm{~kg} \mathrm{~K} 2 \mathrm{O} \cdot \mathrm{m}^{-2}$; and $0.0015 \mathrm{~kg}$ borax $\cdot \mathrm{m}^{-2}$; and $\mathrm{CK}$ represents no fertilizer. The same as Table 2,3 , and 4.

Under the local late sowing date in 2011-2012, the phenology of different nitrogen levels for same cultivars had obvious difference at mature date, and the mature date under $\mathrm{N}$ application conditions were later than that of CK (Table 2).

Table 2. The phenology under different cultivars and nitrogen rate in 2011-2012

\begin{tabular}{|c|c|c|c|c|c|c|}
\hline \multirow{2}{*}{ Cultivars } & \multirow{2}{*}{ Fertilizer } & \multirow{2}{*}{ Sowing date (M-D) } & \multirow{2}{*}{$\begin{array}{l}\text { Emergence date } \\
\text { (M-D) }\end{array}$} & \multirow{2}{*}{$\begin{array}{l}\text { Enlongation date } \\
\text { (M-D) }\end{array}$} & \multirow{2}{*}{$\begin{array}{l}\text { Early anthesis date } \\
\text { (M-D) }\end{array}$} & \multirow{2}{*}{ Mature date(M-D) } \\
\hline & & & & & & \\
\hline \multirow[t]{2}{*}{ NY16 } & $\mathrm{N}$ & $10-15$ & $10-20$ & 03-17 & 04-05 & $05-22$ \\
\hline & $\mathrm{CK}$ & $10-15$ & $10-20$ & 03-17 & $04-05$ & $05-20$ \\
\hline \multirow[t]{2}{*}{ NY18 } & $\mathrm{N}$ & $10-15$ & $10-22$ & 03-17 & 04-04 & $05-21$ \\
\hline & $\mathrm{CK}$ & $10-15$ & $10-22$ & 03-17 & $04-03$ & $05-18$ \\
\hline \multirow[t]{2}{*}{ NZ19 } & $\mathrm{N}$ & $10-15$ & $10-20$ & 03-17 & 04-04 & $05-21$ \\
\hline & $\mathrm{CK}$ & $10-15$ & $10-20$ & 03-17 & 04-03 & $05-18$ \\
\hline
\end{tabular}

3.1.2 Leaf number. Under the local normal sowing date in 2007-2008, and in 2008-2009, the leaf number in main stem of different nitrogen levels had obvious difference only for NY16 (Table 3, and 4), and the leaf number in main stem of different nitrogen levels for NY18, and NZ19 had no obvious difference (Table 3, and 4).

Table 3. The leaf number in main stem under different cultivars and nitrogen rate in 2007-2008

\begin{tabular}{|c|c|c|c|c|c|c|c|c|c|}
\hline \multirow{2}{*}{ Cultivar } & \multirow{2}{*}{ Fertilizer } & \multicolumn{8}{|c|}{ Date (M-D) } \\
\hline & & $10-07$ & 11-03 & $11-25$ & $01-10$ & $02-20$ & 03-04 & 03-12 & $03-27$ \\
\hline \multirow[t]{3}{*}{ NY16 } & $\mathrm{N}$ & 1.5 & 3.1 & 8.9 & 11.2 & 14.2 & 19.1 & 22.2 & 25.8 \\
\hline & CK & 1.5 & 3.1 & 8.8 & 10.4 & 12.5 & 17.5 & 20.9 & 23.3 \\
\hline & $\pm(\mathrm{N}-\mathrm{CK})$ & 0 & 0 & 0.1 & 0.8 & 1.7 & 1.6 & 1.3 & 2.5 \\
\hline \multirow[t]{3}{*}{ NY18 } & $\mathrm{N}$ & 1.5 & 4.1 & 8.9 & 10.7 & 12.8 & 18.1 & 22.6 & 27 \\
\hline & CK & 1.5 & 4.1 & 9.6 & 11.1 & 13.9 & 18.8 & 22.8 & 27.1 \\
\hline & $\pm(\mathrm{N}-\mathrm{CK})$ & 0 & 0 & -0.7 & -0.4 & -1.1 & -0.7 & -0.2 & -0.1 \\
\hline
\end{tabular}


Table 4. The leaf number in main stem under different cultivars and nitrogen rate in 2008-2009

\begin{tabular}{|c|c|c|c|c|c|c|}
\hline \multirow{2}{*}{ Cultivar } & \multirow{2}{*}{ Fertilizer } & \multicolumn{5}{|c|}{ Date (M-D) } \\
\hline & & $11-25$ & $12-16$ & $02-24$ & 03-03 & 03-07 \\
\hline \multirow[t]{3}{*}{ NY16 } & $\mathrm{N}$ & 10.2 & 13.9 & 28.1 & 28.7 & 35.3 \\
\hline & $\mathrm{CK}$ & 10.6 & 13.7 & 26.1 & 27.5 & 33.7 \\
\hline & $\pm(\mathrm{N}-\mathrm{CK})$ & -0.3 & 0.2 & 2.1 & 1.2 & 1.7 \\
\hline \multirow[t]{3}{*}{ NY18 } & $\mathrm{N}$ & 8.2 & 11.1 & 31.6 & 32.0 & 30.3 \\
\hline & $\mathrm{CK}$ & 8.2 & 11.1 & 30.9 & 32.5 & 31.0 \\
\hline & $\pm(\mathrm{N}-\mathrm{CK})$ & -0.1 & 0.0 & 0.7 & -0.5 & -0.7 \\
\hline \multirow[t]{3}{*}{ NZ19 } & $\mathrm{N}$ & 10.3 & 13.2 & 27.2 & 28.0 & 33.3 \\
\hline & CK & 10.2 & 12.9 & 27.1 & 28.0 & 34.0 \\
\hline & $\pm(\mathrm{N}-\mathrm{CK})$ & 0.1 & 0.3 & 0.1 & 0.0 & -0.7 \\
\hline
\end{tabular}

\subsection{The effect factors of nitrogen in the phenology and leaf number sub-model}

3.2.1 Nitrogen content in leaf and silique. Nitrogen content in leaf and silique of various cultivars and nitrogen rate in 2007-2008 shown in Fig.1, and Fig. 2, and the results showed that the nitrogen content in leaf had a peak value at pre-over-wintering ( 8 JAN 2008) under nitrogen application conditions, in contrast, had a vale value at the same time under CK conditions (Fig. 1); the nitrogen content in silique had a peak value around end anthesis under nitrogen application conditions, in contrast, had a vale value at the same time under CK conditions (Fig. 2). It set a basis for developing the effect factor of nitrogen in the next step.
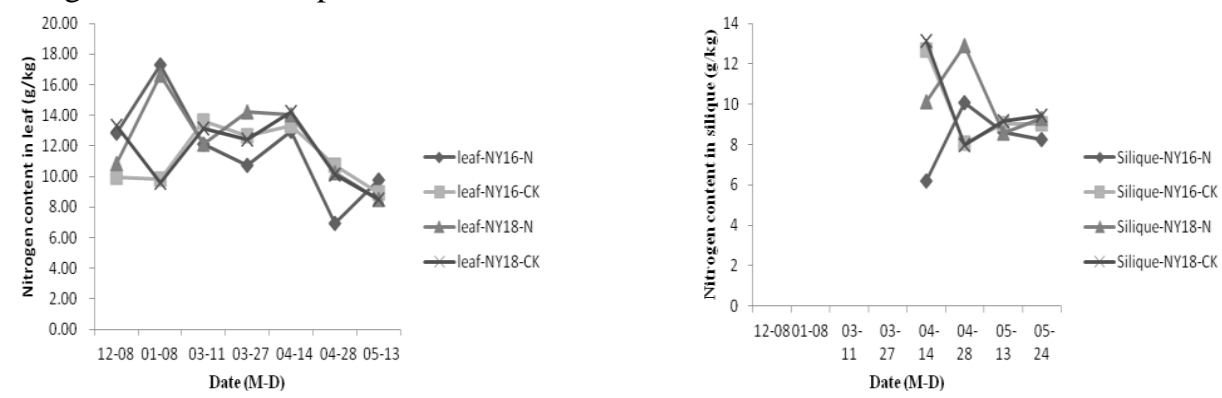
Fig. 1. The nitrogen content in leaf of various cultivars and nitrogen rate in 2007-2008
Fig. 2. The nitrogen content in silique of various cultivars and nitrogen rate in 2007-2008

3.2.2 Effect factor of nitrogen. According to experiment data in 2007-2008, the enlongation date was postponed with nitrogen application, and the mature date was postponed under late sowing condition in 2011-2012. Therefore, the effect factor of nitrogen, $F(N)$, in the phenology sub-model can be expressed as follows:

$$
F(N)= \begin{cases}1 & T R N<T C N \\ \frac{T R N-T C N}{T R N-T L N} & T R N \geq T C N\end{cases}
$$

where $T R N$ is the actual leaf nitrogen content $\left(\mathrm{g} \mathrm{kg}^{-1}\right)$ around $10 \mathrm{~d}$ after fertilizing at pre-over-wintering, $T L N$ is the lowest leaf nitrogen content $\left(\mathrm{g} \mathrm{kg}^{-1}\right)$ in the same time for CK, and $T C N$ is the critical leaf nitrogen content $\left(\mathrm{g} \mathrm{kg}^{-1}\right)$. In that $T L N$ and TCN can be obtained using the experiment data in 2007-2008, taking $T L N=9.58 \mathrm{~g} \mathrm{~kg}^{-1}$ (Fig.1) for CK at pre-over-wintering, and $T C N=9.88 \mathrm{~g} \mathrm{~kg}^{-1}$.

Due to the effects of nitrogen application on leaf numbers in main stem were different with cultivars, and years, the leaf numbers in main stem in sub-model can be verified through adjusting cultivar parameters in leaf number sub-model.

\subsection{The validation of the phenology sub-model after revising}

3.3.1 Parameters of the phenology sub-model. The various parameters of the phenology sub-model were determined using the experiment data in 2008 to 2009 (Table 5). We can see that $k j$, basic development coefficient which was determined by cultivar heredity, was different for various cultivars in the same development stages apart from stage II (emergence to vernalization), and $p j$ (the genotypic coefficient of temperature effects for increasing), $q j$ (the genotypic coefficient of temperature effects for decreasing), and $G j$ (the genotypic coefficient of photoperiod effects) were the same for various cultivars in the same development stages.

\begin{tabular}{cccccc}
\multicolumn{2}{c}{ Table 5. Parameters of models in various development stages for winter rapeseed } \\
\cline { 3 - 6 } Cultivar & Development Stage & \multicolumn{5}{c}{ Parameter of model } \\
\cline { 3 - 6 } & & $\mathrm{kj}$ & $\mathrm{pj}$ & $\mathrm{qj}$ & $\mathrm{Gj}$ \\
\multirow{2}{*}{ NY16 } & I & -1.365 & 0.934 & - & - \\
& II & -2.294 & 1.019 & - & - \\
& III & -3.964 & 0.639 & 2.791 & - \\
& IV & -1.827 & 0.777 & - & - \\
& V & -4.041 & 0.588 & - & 0.065 \\
\hline \multirow{2}{*}{ NY18 } & I & -1.336 & 0.934 & - & - \\
& II & -2.294 & 1.019 & - & - \\
& III & -4.014 & 0.639 & 2.791 & - \\
& IV & -1.767 & 0.777 & - & - \\
& V & -4.028 & 0.588 & - & 0.065 \\
\hline
\end{tabular}




\begin{tabular}{cccccc}
\hline $\mathrm{NZ19}$ & II & -2.294 & 1.019 & - & - \\
& III & -3.778 & 0.639 & 2.791 & - \\
& IV & -1.539 & 0.777 & - & - \\
& V & -3.905 & 0.588 & - & 0.065
\end{tabular}

Note: j represents development stage I (planting to emergence), II (emergence to vernalization), III

(vernalization to enlongation), IV (enlongation to early anthesis), and V (early anthesis to mature).

3.3.2 The validation of the phenology sub-model after revising. The comparison between phenology with $\mathrm{F}(\mathrm{N})$ and no $\mathrm{F}(\mathrm{N})$ were shown in Table 6, and Table 7, Fig.3, and Fig.4. The results showed that the phenology with $\mathrm{F}(\mathrm{N})$ were more close to the observed values of nitrogen treatments (Table 1 , and Table 2), and the RMSE, $R^{2}, d_{a}$, and $d_{a p}$ between observed and simulated values with for the same cultivars in 2007-2008, and in 2011-2012 were $0.77 \mathrm{~d}, 0.9998,-0.20 \mathrm{~d}$, and $0.1715 \% ; 1.45 \mathrm{~d}, 0.9998,-0.90 \mathrm{~d}$, and $0.8295 \%$. We can see that precision of the phenology sub-model was raised further.

Table 6. The comparison between phenology with $F(N)$ and no $F(N)$ in 2007-2008

\begin{tabular}{|c|c|c|c|c|c|c|}
\hline \multirow[b]{2}{*}{ Cultivars } & \multirow[b]{2}{*}{$\mathrm{F}(\mathrm{N})$} & \multirow[b]{2}{*}{ Sowing date (M-D) } & \multirow{2}{*}{$\begin{array}{l}\text { Emergence } \\
\text { (M-D) }\end{array}$} & \multicolumn{3}{|c|}{ Early anthesis } \\
\hline & & & & Enlongation (M-D) & (M-D) & Mature (M-D) \\
\hline \multirow[t]{2}{*}{ NY16 } & - & $09-26$ & $09-29$ & 03-08 & $03-25$ & $05-16$ \\
\hline & + & $09-26$ & $09-29$ & 03-10 & $03-26$ & $05-17$ \\
\hline \multirow[t]{2}{*}{ NY18 } & - & $09-26$ & $09-29$ & 03-08 & $03-25$ & $05-16$ \\
\hline & + & $09-26$ & $09-29$ & 03-10 & $03-26$ & $05-17$ \\
\hline
\end{tabular}

Note: + and - denoted the phenology with $\mathrm{F}(\mathrm{N})$ and no $\mathrm{F}(\mathrm{N})$. The same as Table 7.

Table 7. The comparison between phenology with $\mathrm{F}(\mathrm{N})$ and no $\mathrm{F}(\mathrm{N})$ in 2011-2012

\begin{tabular}{|c|c|c|c|c|c|c|}
\hline \multirow[b]{2}{*}{ Cultivars } & \multirow[b]{2}{*}{$\mathrm{F}(\mathrm{N})$} & \multirow{2}{*}{$\begin{array}{l}\text { Sowing date } \\
\text { (M-D) }\end{array}$} & \multirow[b]{2}{*}{ Emergence (M-D) } & \multirow{2}{*}{$\begin{array}{l}\text { Enlongation } \\
\text { (M-D) }\end{array}$} & \multirow{2}{*}{ Early anthesis } & \multirow[b]{2}{*}{ Mature (M-D) } \\
\hline & & & & & & \\
\hline NY16 & + & $10-15$ & $10-19$ & 03-18 & 04-03 & $05-21$ \\
\hline \multirow[t]{2}{*}{ NY18 } & - & $10-15$ & $10-19$ & $03-20$ & 04-01 & 05-19 \\
\hline & + & $10-15$ & $10-19$ & 03-20 & 04-03 & $05-22$ \\
\hline
\end{tabular}




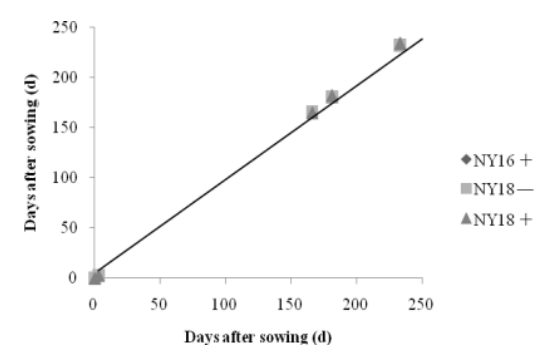

Fig. 3. The 1:1 diagram between phenology with $F(N)$

and no $\mathrm{F}(\mathrm{N})$ in 2007-2008

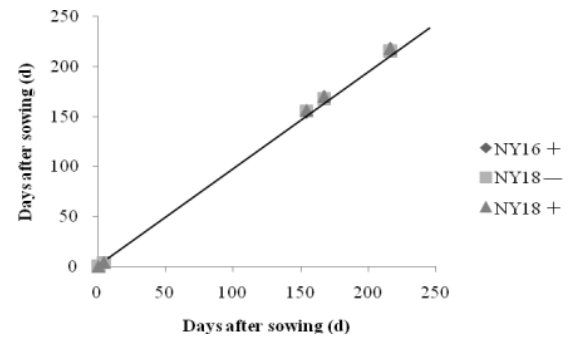

Fig. 4. The 1:1 diagram between phenology with $F(N)$

and no $\mathrm{F}(\mathrm{N})$ in 2011-2012

\section{Discussion}

4.1 The application of phenology in rapeseed growth models in region and site scales. The rapeseed growth models need to be verified using the nitrogen impact factor when they will be applied in region and site scales. The effect factor of nitrogen, $F(N)$, was gained according to different yield level types in region scale, and according to fertilizer level in site scale. Due to the calculation of $F(N)$ need to obtain the TRN (actual leaf nitrogen content), TCN (critical leaf nitrogen content), and TLN (lowest leaf nitrogen content (g $\mathrm{kg}^{-1}$ ) around $10 \mathrm{~d}$ after fertilizing at pre-over-wintering for $\mathrm{CK}$ ) values under the local condition, and it should be tested in different sites. CERES-Rape [5] also had modules for crop phenology, net photosynthesis, leaf area development, and grain filling, as influenced by crop N status. Chen et al. [20] studied fruit-per-plant model for protected tomato using fertilizer factor, describing the effects of nitrogen on fruit-per-plant for protected tomato.

The phenology and leaf number in rapeseed were affected by multi-factors, which were decided by genotypes and environmental factors, and temperature and light in environmental factors were main factors of them. In addition, the phenology was also affected by fertilizer, water, and so on. However, the nitrogen impact factor, $F(N)$, was only introduced into the phenology model in this paper. The water impact factor should be considered in future studies. As to the relationship between leaf number in main stem in rapeseed and nitrogen application, it was different under various cultivars, and needed to be studied further.

4.2 The effect factor of nitrogen. It was determined according to the changes in nitrogen content in leaf and silique of various cultivars and nitrogen rates (Fig. 1, and Fig. 2), and because leaf nitrogen content, TRN, can be acquired easily comparing with silique, the actual leaf nitrogen content around $10 \mathrm{~d}$ after fertilizing at pre-over-wintering was introduced to the effect factor of nitrogen.

4.3 The phenology difference of different nitrogen levels for various years. Why difference of the phenology of different nitrogen levels during 2007-2008 was at 
enlongation, while that of during 2011-2012 was at mature, the reason maybe was from higher month average temperature, and lower month rainfall in that time comparing with the normal year, e.g., MAR 2008 (the month average temperature was higher than the normal year at $2.6^{\circ} \mathrm{C}$, but the rainfall was lower than the normal year at $49.6 \mathrm{~mm}$ ), MAY 2012 (the month average temperature was higher than the normal year at $1.4^{\circ} \mathrm{C}$, but the rainfall was lower than the normal year at $39.7 \mathrm{~mm}$ ) (Table 8 and Table 9).

Table 8. The comparison of month value of meteorological conditions during 2007 to 2008 and that of the normal year in Nanjing (data from Center for China Meteorological Information of China Meteorological Bureau)

\begin{tabular}{|c|c|c|c|c|c|c|c|c|c|c|c|}
\hline Year & Month & $\begin{array}{l}\text { Average } \\
\text { temperature } \\
\left({ }^{\circ} \mathrm{C}\right)\end{array}$ & $\begin{array}{c} \pm(\text { AT-NY }) \\
\left({ }^{\circ} \mathrm{C}\right)\end{array}$ & $\begin{array}{c}\text { Average min } \\
\text { temperature } \\
\left({ }^{\circ} \mathrm{C}\right)\end{array}$ & $\begin{array}{c} \pm(\text { ANT-NY }) \\
\left({ }^{\circ} \mathrm{C}\right)\end{array}$ & $\begin{array}{c}\text { Average max } \\
\text { temperature } \\
\left({ }^{\circ} \mathrm{C}\right)\end{array}$ & $\begin{array}{c} \pm(\text { AXT-NY) } \\
\left({ }^{\circ} \mathrm{C}\right)\end{array}$ & $\begin{array}{l}\text { Sun } \\
\text { times } \\
\text { (hr.) }\end{array}$ & $\begin{array}{c} \pm(\text { ST-NY) } \\
\text { (hr.) }\end{array}$ & $\begin{array}{l}\text { Rainfall } \\
(\mathrm{mm})\end{array}$ & $\begin{array}{c} \pm(\mathrm{R}-\mathrm{NY}) \\
(\mathrm{mm})\end{array}$ \\
\hline \multirow[t]{8}{*}{2007} & 9 & 24.1 & 1.3 & 20.5 & 1.3 & 28.2 & 0.9 & 135.3 & -31.9 & 127.4 & 55.3 \\
\hline & $\mathrm{NY}$ & 22.8 & & 19.2 & & 27.3 & & 167.2 & & 72.1 & \\
\hline & 10 & 18.5 & 1.4 & 15 & 2. 1 & 23.1 & 0.9 & 153.4 & -15.7 & 39.7 & -25.4 \\
\hline & $\mathrm{NY}$ & 17.1 & & 12.9 & & 22.2 & & 169.1 & & 65.1 & \\
\hline & 11 & 11.2 & 0.8 & 6.7 & 0.6 & 16.8 & 0.9 & 161.3 & 7.8 & 23.7 & -27.1 \\
\hline & $\mathrm{NY}$ & 10.4 & & 6.1 & & 15.9 & & 153.5 & & 50.8 & \\
\hline & 12 & 6.7 & 2.2 & 4. 1 & 3.7 & 10.2 & 0.2 & 49.6 & -100.6 & 40.7 & 16. 2 \\
\hline & $\mathrm{NY}$ & 4.5 & & 0.4 & & 10 & & 150.2 & & 24.5 & \\
\hline \multirow[t]{11}{*}{2008} & 1 & 1.5 & -0.9 & -1 & 0.1 & 4.9 & -2.1 & 56.1 & $\begin{array}{l}-73 \\
\end{array}$ & 110.1 & 72.7 \\
\hline & $\mathrm{NY}$ & 2.4 & & -1.1 & & 7 & & 129.1 & & 37.4 & \\
\hline & 2 & 2.5 & -1.7 & -1.7 & -2.3 & 7.6 & -1.2 & 194.1 & 70.8 & 18.9 & -28.2 \\
\hline & $\mathrm{NY}$ & 4.2 & & 0.6 & & 8.8 & & 123.3 & & 47.1 & \\
\hline & 3 & 11.3 & 2.6 & 6.7 & 1.9 & 16. 9 & 3.5 & 185.8 & 49.7 & 32.2 & -49.6 \\
\hline & $\mathrm{NY}$ & 8.7 & & 4.8 & & 13.4 & & 136.1 & & 81.8 & \\
\hline & 4 & 15.6 & 0.4 & 11.7 & 1.1 & 20.4 & 0.1 & 146 & -22.1 & 90 & 16.6 \\
\hline & $\mathrm{NY}$ & 15.2 & & 10.6 & & 20.3 & & 168.1 & & 73.4 & \\
\hline & $\mathrm{NY}$ & 20.5 & & 15.9 & & 25.6 & & 194 & & 102.1 & \\
\hline & 6 & 23.5 & -0.9 & 20.6 & -0.1 & 27.2 & -1.6 & 71.1 & -100.8 & 131.7 & -61.7 \\
\hline & $\mathrm{NY}$ & 24.4 & & 20.7 & & 28.8 & & 171.9 & & 193.4 & \\
\hline
\end{tabular}

Note: NY, AT, ANT, AXT, ST, and R denoted the normal year, average temperature, average min temperature, average max temperature, sun times, and rainfall, respectively. The same as Table 8 .

Table 9 The comparison of month value of meteorological conditions during 2011- 2012 and that of the normal year in Nanjing (data from Center for China Meteorological Information of China Meteorological Bureau)

\begin{tabular}{|c|c|c|c|c|c|c|c|c|c|c|c|}
\hline Year & Month & $\begin{array}{c}\text { Average } \\
\text { temperature } \\
\left({ }^{\circ} \mathrm{C}\right)\end{array}$ & $\begin{array}{c} \pm(\mathrm{AT}-\mathrm{NY}) \\
\left({ }^{\circ} \mathrm{C}\right)\end{array}$ & $\begin{array}{c}\text { Average min } \\
\text { temperature } \\
\left({ }^{\circ} \mathrm{C}\right)\end{array}$ & $\begin{array}{c} \pm(\text { ANT-NY }) \\
\left({ }^{\circ} \mathrm{C}\right)\end{array}$ & $\begin{array}{c}\text { Average max } \\
\text { temperature } \\
\left({ }^{\circ} \mathrm{C}\right)\end{array}$ & $\begin{array}{c} \pm(\text { AXT-NY }) \\
\left({ }^{\circ} \mathrm{C}\right)\end{array}$ & $\begin{array}{l}\text { Sun } \\
\text { times } \\
\text { (hr.) }\end{array}$ & $\begin{array}{c} \pm(\text { ST-NY }) \\
(\mathrm{hr} .)\end{array}$ & $\begin{array}{l}\text { Rainfall } \\
(\mathrm{mm})\end{array}$ & $\begin{array}{c} \pm(\mathrm{R}-\mathrm{NY}) \\
(\mathrm{mm})\end{array}$ \\
\hline \multirow[t]{7}{*}{2011} & 9 & 23.2 & 0.4 & 20.1 & 0.9 & 27.3 & 0 & 157.2 & -10 & 12.6 & -59.5 \\
\hline & NY & 22.8 & & 19.2 & & 27.3 & & 167.2 & & 72.1 & \\
\hline & 10 & 17.6 & 0.5 & 14.3 & 1. 4 & 21.9 & -0.3 & 155.3 & -13.8 & 28.7 & -36.4 \\
\hline & NY & 17.1 & & 12.9 & & 22.2 & & 169.1 & & 65.1 & \\
\hline & 11 & 14.7 & 4.3 & 11.6 & 5.5 & 19.3 & 3.4 & 133.4 & -20.1 & 21.3 & -29.5 \\
\hline & NY & 10.4 & & 6.1 & & 15.9 & & 153.5 & & 50.8 & \\
\hline & NY & 4.5 & & 0.4 & & 10 & & 150.2 & & 24.5 & \\
\hline \multirow[t]{6}{*}{2012} & 1 & 2.9 & 0.5 & 0.2 & 1.3 & 6.4 & -0.6 & 100.5 & -28.6 & 21 & -16.4 \\
\hline & NY & 2.4 & & -1.1 & & 7 & & 129.1 & & 37.4 & \\
\hline & 2 & 3 & -1.2 & 0.3 & -0.3 & 6.3 & -2.5 & 87.9 & -35.4 & 73.3 & 26.2 \\
\hline & NY & 4. 2 & & 0.6 & & 8.8 & & 123.3 & & 47.1 & \\
\hline & 3 & 9 & 0.3 & 5.4 & 0.6 & 13.4 & 0 & 128.8 & -7.3 & 79.3 & -2.5 \\
\hline & NY & 8.7 & & 4.8 & & 13.4 & & 136.1 & & 81.8 & \\
\hline
\end{tabular}




\begin{tabular}{|c|c|c|c|c|c|c|c|c|c|c|}
\hline 4 & 17.9 & 2.7 & 13.3 & 2.7 & 23.4 & 3.1 & 189.2 & 21.1 & 56.2 & -17.2 \\
\hline NY & 15.2 & & 10.6 & & 20.3 & & 168.1 & & 73.4 & \\
\hline 5 & 21.9 & 1.4 & 17.5 & 1.6 & 26.9 & 1.3 & 198 & 4 & 62.4 & -39.7 \\
\hline NY & 20.5 & & 15.9 & & 25.6 & & 194 & & 102.1 & \\
\hline & 24.4 & & 20.7 & & 28.8 & & 171.9 & & 193.4 & \\
\hline
\end{tabular}

\section{Coclusions}

This paper presented an attempt at validating and perfecting of phenology, and leaf number sub-model in rapeseed growth models. Through the 3 year field experiment data analysis, we can conclude that the phenology in rapeseed models had obvious difference for the same cultivar under different nitrogen levels. Thus, the nitrogen effect factors were put forward and used in the phenology sub-model in rapeseed growth models, and the verification of the leaf number sub-model can be done through model parameter adjusting. The simulated values before and after using nitrogen effect factors and the observed values were compared, and the precision for the phenology sub-models with nitrogen effect factors in rapeseed growth models were raised further.

\section{APPENDIX}

\section{A. Phenology}

The basic models of rapeseed phenology were developed in the thesis through employing ideal of "Rice Clock Models" [11-14][17-18].

$$
\begin{aligned}
& d P_{j} / d t=1 / D_{S j}=e^{k j} \cdot\left(T_{e b j}\right)^{p j} \cdot\left(T_{e u j}\right)^{q j} \cdot\left(P_{e j}\right)^{G j} \cdot \mathrm{f}\left(E_{C i}\right) \\
& T_{e b j}=\left(T_{i}-T_{b j}\right) /\left(T_{o j}-T_{b j}\right), \text { when } T_{i}<T_{b j}, T_{i}=T_{b j} ; \text { when } T_{i}>T_{o j}, T_{i}=T_{o j} \\
& T_{e u j}=\left(T_{u j}-T_{i}\right) /\left(T_{u j}-T_{o j}\right), \text { when } T_{i}>T_{u j}, T_{i}=T_{u j} \\
& P_{e j}=\left(P_{i}-P_{b j}\right) /\left(P_{o j}-P_{b j}\right), \text { when } P_{i}<P_{b j}, P_{i}=P_{b j} \text {, when } P_{i}>P_{o j}, P_{i}=P_{o j}
\end{aligned}
$$

where $d P_{j} / d t$ is the development rate at the $j^{\text {th }}$ stages, $D_{S j}$ is the days at the $j^{\text {th }}$ stages, $T_{e b j}$ and $T_{e u j}$ are the effective factors for temperature, respectively, $k j$ is basic development parameter which is determined by cultivar heredity, $p j$ and $q j$ are the genotypic coefficient of temperature effects, $P_{e j}$ is the effective factor of photoperiod, $G j$ is the genotypic coefficient of photoperiod effects, and $f\left(E_{C i}\right)$ is the effective function of agronomic practice factors for rapeseed, $T_{i}$ is the daily mean temperature $\left({ }^{\circ} \mathrm{C}\right)$ in the $j^{\text {th }}$ stage, $T_{b j}, T_{o j}$ and $T_{u j}$ are lower, optimum, and upper limit temperature $\left({ }^{\circ} \mathrm{C}\right)$ demanded in the $\mathrm{j}^{\text {th }}$ stage for rapeseed, respectively, and $P_{b j}, P_{o j}$ are the critical and optimum day length (h) demanded in $j^{\text {th }}$ stage for rapeseed, respectively.

Vernalization models can be described as following through employing ideals of "wheat clock models":

$$
d V / d t=1 / D_{s 2}=e^{k 2} \cdot\left(V_{e}\right)^{C}
$$

If a cultivar was winter or semi-winter rapeseed, the expression of $V_{e}$ was: 


$$
V_{\mathrm{e}}=\left\{\begin{array}{c}
\frac{\mathrm{V}_{\mathrm{ti}}+4}{9},-4<\mathrm{V}_{\mathrm{ti}} \leq 5^{\circ} \mathrm{C} \\
9.0_{2}, \quad 5<\mathrm{V}_{\mathrm{ti}} \leq 10^{\circ} \mathrm{C} \\
\frac{20-\mathrm{V}_{\mathrm{ti}}}{10}, 10<\mathrm{V}_{\mathrm{ti}} \leq 20^{\circ} \mathrm{C} \\
0, \mathrm{~V}_{\mathrm{ti}} \leq-4{ }^{\circ} \mathrm{C} \text { or } \mathrm{V}_{\mathrm{ti}}>20^{\circ} \mathrm{C}
\end{array}\right.
$$

However, if it was spring rapeseed, the expression of $\mathrm{V}_{\mathrm{e}}$ was:

$$
V_{e}=\left\{\begin{array}{c}
\frac{V_{t i}}{5}, 0<V_{t i} \leq 5^{\circ} \mathrm{C} \\
\frac{1,0_{i}}{30-V_{t i}} \quad 5<V_{t i} \leq 20^{\circ} \mathrm{C} \\
10,20<V_{t i} \leq 30^{\circ} \mathrm{C} \\
0, V_{t i} \leq 0^{\circ} \mathrm{C} \text { or } V_{t i}>30^{\circ} \mathrm{C}
\end{array}\right.
$$

where $K 2$ and $C$ are the parameters of vernalization, $V_{e}$ is the factor of rapeseed vernalization effect, $V_{t i}$ is the daily mean temperature in vernalization phase. It will finish vernalization phase when $V_{e}$ equal to some extent accumulation days; the vernalization days of the winter rapeseed were 30 to 40 days, the semi-winter rapeseed with 20 to 30 days, and the spring rapeseed with 15 to 20 days.

\section{B. Leaf number}

The growth rate of rapeseed leaf were different in different varieties, development stages, temperature, and nutrition conditions etc., when nutrition condition was optimum, the models of rapeseed leaf number were [11-14][17-18] :

$$
\begin{aligned}
& d L_{j} / d t=f\left(L_{j}\right)=1 / D_{L j}=D_{L o j} \cdot\left(T_{t} / T_{o}\right)^{L a l L b} \\
& \mathrm{~T}_{\mathrm{t}}= \begin{cases}0_{o} & \text { when } \mathrm{T}_{\mathrm{t}}<\mathrm{T}_{\mathrm{bj}} \\
\mathrm{T}_{\mathrm{o}^{x}} & \text { when } \mathrm{T}_{\mathrm{t}}>\mathrm{T}_{\mathrm{o}}\end{cases} \\
& D_{L o j}=e^{L K}
\end{aligned}
$$

where $d L_{j} / d t$ is the development rate of the $j^{\text {th }}$ leaf , $f\left(L_{j}\right)$ is the basic development function, $D_{L j}$ is the development days demanded from emergence to the $j^{\text {th }}$ leaf number, $D_{L o j}$ is the development days demanded from emergence to the $j^{\text {th }}$ leaf number under the optimum conditions, $T_{t}$ and $T_{o}$ are the daily mean temperature $\left({ }^{\circ} \mathrm{C}\right)$ of the $t^{\text {th }}$ day, and the optimum temperature for rapeseed leaf number development, respectively, and $L a, L b$, and $L K$ are the parameters of leaf models, respectively.

\section{Acknowledgement}

The authors would like to express their appreciation to Prof. Cunkou Qi, Huiming Pu, and Xinjun Chen of the Institute of Economic Crop Research, Jiangsu Academy of Agricultural Sciences, China, for providing trial materials. This work was supported by the National Natural Science Foundation of China $(31171455 ; 31201127 ; 31471415)$, the National High-tech R\&D Project (2013AA102305), the Jiangsu Province Agricultural Scientific Technology Innovation Fund, China (CX(12)5061), the Agricultural Scientific Technology Support Program, Jiangsu Province, China (BE2011342; BE2012386), the 
No-Profit Industry (Meteorology) Research Program, China (GYHY201106027), and the Jiangsu Government Scholarship for Overseas Studies, China.

\section{References}

1. National Bureau of Statistics of China. 2009. [2013-09-26]. http://www.stats.gov.cn/tjsj/qtsj/gjsj/.

2. J. R. Kiniry, D. J. Major, R. C. Izaurralde, et al. EPIC model parameters for cereal, oilseed, and forage crop in the north Great Plain region [J]. Canadian Journal of Plant Science, 1983, 63, 1063-1065.

3. C. T. Petersen, H. Svendsen, S. Hansen, et al. Parameter assessment for simulation of biomass production and nitrogen uptake in winter rape [J]. Europe Journal of Agronomy, 1995, 4, 77-89.

4. B. Habekotté. A model of the penological development of winter oilseed rape (Brassica napus L.) [J]. Field Crop Research, 1997, 54, 137-153.

5. B. Gabrielle, P. Denoroy, G. Gosse, et al. Development and evaluation of a CERES-type model for winter oilseed rape [J]. Field Crop Research, 1998, 57, 95-111.

6. M. J. Farré, G. H. Robertson, S. A. Walton. Simulating response of canola to sowing data in Western Australia [M]. Proceedings of the $10^{\text {th }}$ Australia Agronomy Conference, Hobart, 2001, $36-40$.

7. F. Husson, D. Wallach, A. Vandeputte. Evaluation of CECOL, a model of winter rape (Brassica napus L.) [J]. Europe Journal of Agronomy, 1998, 8, 205-214.

8. Liu Hong, Jin Zhiqing. The simulation models of rape development dynamic [J]. Journal of application meteorology, 2003, 14(5): 634-640. (in Chinese with English abstract)

9. Liu Tiemei, Hu Liyong, Zhao Zuhong, et al. A mechanistic of phasic and phenological development in rape. I. Description of the model [J]. Chinese journal of oil crop sciences, 2004, 26(1): 27-30. (in Chinese)

10. Zhang Charles, Li Guangming, Cao Hongxin, et al. Simulating growth and development of winter rape in Yangtze river valley $[\mathrm{M}]$. in: Proceedings of 11th International Rapeseed Congress, Copenhagen, Denmark, 6.-10. July, 2003, 835.

11. Cao Hongxin, Zhang Charles, Li Guangming, et al. Researches of Decision-making System for Rape Optimization-Digital Cultivation Based on Simulation Models [M]. in: The Third International Conference on Intelligent Agricultural Information Technology, Beijing: China Agricultural Sciences and Technology Press, 2005, 285-292.

12. Cao Hongxin, Zhang Charles, Li Guangming, et al. Researches of Simulation Models of Rape (Brassica napus L.) Growth and Development [J]. ACTA AGRONOMICA SINICA, 2006, 32(10), 1530-1536. (in Chinese with English Abstract)

13. Cao Hongxin, Zhang Charles, Li Guangming, et al. Researches of Optimum Leaf Area Index Dynamic Models for Rape (Brassica napus L.) [M]. in: IFIP International Federation for Information Processing, Volume 295, Computer and Computing Technologies in Agriculture II, Volume 3, eds. D. Li, Z. Chunjiang, (Boston: Springer), 2009, 1585-1594.

14. Cao Hongxin, Zhang Charles, Li Guangming, et al. Researches of Optimum Shoot and Ramification Number Dynamic Models for Rapeseed (Brassica napus L.) [M]. in: World Automation Congress (WAC), 2010, 129-135.

15. Tang, Liang. 2006. Rapeseed growth simulation and decision-making support system [M]. Dissertation for Ph.D. of Nanjing Agricultural University. 
16. Tang Liang, Zhu Yan, Liu Tiemei, et al. A Process-Based Model for Simulating Phenological Development in Rapeseed [J]. Scientia Agricultura Sinica, 2008, 41(8): 2493-2498. (in Chinese with English abstract)

17. Gao Liangzhi, Jin Zhiqing, Huang Yao, et al. Rice cultivational simulation-optimization-decision making system [M]. Chinese Agricultural Sciences and Technology Publication House, 1992, Beijing, China. (in Chinese with English abstract)

18. Gao Liangzhi, Jin Zhiqing, Zheng Guoqing, et al. Wheat cultivational simulation-optimization-decision making system [J]. Journal of Jiangsu Agriculture, 2000, 16, 65-72. (in Chinese with English abstract)

19. Cao Hongxin, Jim S. Hanan, Liu Yongxia, et al. Comparison of crop model validation methods [J]. Journal of Integrative Agriculture (formerly Agricultural Sciences in China), 2012, 11(8): 1274-1285.

20. Chen Yuli. Modeling of nitrogen accumulation and partitioning in plant and yield formation for protected cultivated tomato (Lycopersicon esculentum Mill.) [M]. M.D Paper of Nanjing Agricultural University, 2012. 